Шаталов О. С., к.С.-Г.н., доцент, Кусковець С. Л., к.т.н., доцент (Національний університет водного господарства та природокористування, м. Рівне)

\title{
МЕТОДОЛОГІЧНІ ОСНОВИ ОЦІНКИ СОЦІАЛЬНИХ НАСЛІДКІВ СМЕРТЕЛЬНОГО ВИРОБНИЧОГО ТРАВМАТИЗМУ
}

Наведений аналіз можливостей показників статистичного методу оцінки виробничого травматизму та його наслідків. Визначені недоліки класичних підходів до оцінки виробничого травматизму зі смертельним наслідком. Запропоновано оцінку соціальних наслідків виробничого травматизму з урахуванням важкості нещасних випадків на підставі показника трудових втрат. Встановлені межі та умови використання запропонованого показника. Здійснена апробація запропонованої оцінки соціальних наслідків при аналізі виробничого травматизму.

Ключові слова: аналіз, метод, наслідки, показник, праця, травматизм, фактор.

У галузі охорони праці здійснення моніторингу за виробничим травматизмом включає систему спостереження, аналіз рівня виробничого травматизму та вчасне попередження небажаних процесів і наслідків. Сьогодні в Україні нормативно-правові акти, на підставі яких здійснюється проведення моніторингових спостережень за виробничим травматизмом, не мають чітко встановлених його показників, а аналіз проводиться на підставі зібраних даних щодо нещасних випадків на виробництві, у тому числі зі смертельним наслідком. Тому, точність оцінки рівня виробничого травматизму та ефективність працеохоронних заходів прийнятих на підставі ії результатів залежать від достовірності й об'єктивності показників, що відображають його рівень.

Традиційно аналіз рівня виробничого травматизму базується на показниках статистичного методу: показники частоти і тяжкості виробничого травматизму та показник трудових затрат (загальний показник травматизму) [1; 2]. Ці показники використовуються для формування політики і програм попередження професійних захворювань та виробничого травматизму в тому числі смертельного. Також можуть бути використані показники оцінки наслідків професійних 
травм для визначення зайнятості та професійної активності в підрозділах, де мали місце нещасні випадки, планування превентивних заходів та визначення їх пріоритетності й ефективності, здійснення моніторингу ризику [3-5].

Однак, як і всі методи аналізу виробничого травматизму, наведені показники статистичного методу мають ряд недоліків. Основним з них $€$ не відповідність тренду загального показника травматизму його динаміці за роки спостереження та не врахування ним тяжкості нещасних випадків зі смертельним наслідком, як таких, що мають найбільш трагічні наслідки.

У науковій літературі та нормативних актах запропоновано ряд показників які виражають рівень виробничого травматизму та дають його кількісну оцінку. В аналізі виробничого травматизма статистичним методом, використовується показник його тяжкості, який, в деякій мірі, відображає якісний характер цього явища. Класичний вираз даного показника являє собою відношення кількості днів непрацездатності за звітний період до загальної кількості нещасних випадків за той же період. Таке вираження показника тяжкості не дає можливості врахувати ті нещасні випадки, що закінчились смертельним наслідком чи настанням каліцтва. Таким чином, зазначені нещасні випадки залишаються поза увагою і не оцінюються як шкода нанесена суспільству, а сприймається як факт.

У процентному виразі показник нещасних випадків із смертельним наслідком та каліцтвом являє собою відношення кількості нещасних випадків, що призвели до смерті й каліцтва до загальної кількість нещасних випадків.

У роботі [1, С. 23], запропоновано використання у статистичній звітності показника частоти смертельного травматизму $\left(K_{4 c}\right)$, який визначається відношенням кількості нещасних випадків за звітний період із втратою працездатності на один і більше днів до середньоспискової чисельності працюючих за той же період.

Серед показників рекомендованих Міжнародною організацією праці і визначаючих достойну працю [3, С. 156], є такий, що характеризує рівень смертності від професійного травматизму $\left(C_{n m}\right)$ і визначається відношенням кількості смертельних нещасних випадків упродовж звітного періоду до загальної чисельності працівників, що працювали у тому ж періоді. Неведений показник приведений до 100000 працюючих і може застосовуватись лише для аналізу смертельного травматизму в межах галузі чи регіону.

Усі вище наведені показники є класичними і виражають кількі- 
сну оцінку рівня виробничого травматизму і не враховують його соціально-економічну складову, як найбільш небезпечного явища у суспільстві. Для врахування цього закордонними та вітчизняними фахівцями в галузі охорони праці запропоновані показники частоти смертельного професійного травматизму [3, С. 156] і показник частоти травматизму з урахуванням його наслідків [6, С. 73].

Частота смертельності професійного травматизму надає інформацію про кількість смертельних нещасних випадків, що припадає на години які відпрацьовані працівниками впродовж звітного періоду і визначається за формулою:

$$
\Psi_{c n m}=\frac{n_{н в m}}{T} \times 1000000,
$$

де $n_{c н в}$ - кількість смертельних нещасних випадків травматизму впродовж звітного періоду;

$T$ - загальна кількість годин, відпрацьованих працівниками впродовж звітного періоду.

Наведений у формулі (1) показник визначає ймовірність настання небажаної події впродовж визначеного періоду часу, що в свою чергу, у вітчизняній науковій літературі $€$ мірою ризику настання смертельного виробничого травматизму впродовж впливу небезпечних виробничих факторів $[1 ; 2 ; 4 ; 5]$.

Для врахування різних наслідків виробничого травматизму при визначенні його частоти запропоновано використовувати наступний вираз [6]:

$$
K_{u}=\frac{\left(5 N_{c}+2 N_{B}+n \times N_{2}+N_{л}\right)}{N_{p}},
$$

де $N_{c}$ - кількість нещасних випадків зі смертельними наслідками;

$N_{\text {в }}$ - кількість нещасних випадків з важкими наслідками (більше 60 днів непрацездатності);

$N_{r}-$ кількість групових нещасних випадків;

п - кількість потерпілих у групових нещасних випадках;

$N_{л}$ - кількість нещасних випадків з легкими наслідками (від 1 до 60 днів непрацездатності);

$N_{p}$ - загальна чисельність робітників підприємства.

Недоліком підрахунку частоти виробничого травматизму з урахуванням наслідків за даним виразом $€$ те, що вони враховуються лише множниками - 5 і 2. Тобто, як видно з формули (2), наслідок смертельного нещасного випадку в 5 разів важчий ніж нещасний випадок з легким наслідком і у 2 рази ніж з важким наслідком відповідно. 
У роботі [6] для врахування наслідків виробничого травматизму запропоновано інший показник, який дає можливість, в деякій мірі, врахувати соціальну складову смертельного виробничого травматизму - коефіцієнт втрат (термін за [6]). Даний коефіцієнт визначається за формулою:

$$
K_{B}=\frac{\left(60-T_{n}\right) \times n_{c M}+D}{N},
$$

де $T_{n}$ - вік потерпілого (повних років);

$\Pi_{c m}$ - кількість нещасних випадків зі смертельним наслідком;

$D$ - умовна кількість днів непрацездатності потерпілих у нещасних випадках зі смертельним наслідком;

$N$ - загальна кількість працюючих.

Недоліком запропонованого коефіцієнта $€$ те, що для визначення коефіцієнта втрат за (3) всі потерпілі повинні бути одного віку $\left(T_{n}-\right.$ const) або даний коефіцієнт враховує наслідки для кожного смертельного нещасного випадку окремо $\left(n_{C M}=1\right)$.

Таким чином, необхідним $є$ вдосконалення методів оцінки виробничого травматизму зі смертельним наслідком враховуючі соціальну складову цього явища, як такого, що має найбільш небажані наслідки.

Метою дослідження $є$ розробка шляхів підвищення достовірності та об'єктивності статистичного методу аналізу виробничого травматизму зі смертельним наслідком чи каліцтвом за допомогою використання показника соціальних наслідків.

Вирішити поставлену мету пропонується шляхом введення показника соціальних втрат для більш точнішої та об'єктивнішої оцінки шкоди нанесеної суспільству внаслідок смертельного виробничого травматизму та розширення можливостей статистичного методу аналізу виробничого травматизму враховувати наслідки смертельних нещасних випадків і випадків з каліцтвом. Значення цього показника визначається за формулою:

$$
K_{c .8 .}^{c M / \kappa}=\frac{D_{c M / \kappa}^{y M}}{N}
$$

де $D^{y м}{ }_{c M / k}$ - кількість днів умовної непрацездатності працівників 3 якими стались нещасні випадки зі смертельним наслідком чи каліцтвом;

$N_{c M}$ - загальна чисельність працівників впродовж звітного періоду (року).

Днями умовної непрацездатності працівників які загинули від нещасного випадку чи отримали каліцтво пропонується рахувати дні 
можливої професійної активності цих працівників до досяжності ними пенсійного віку за умови не настання нещасного випадку. Визначення умовної непрацездатності таких працівників здійснюється за формулою:

$$
D_{c M / \kappa}=\sum\left(\left[T_{n \varepsilon}-T_{n}\right] \times D_{p d}-D_{\text {вidnp }}\right),
$$

де $T_{п в}$ - вік виходу працівника на пенсію;

$T_{n}$ - вік (повних років) загиблого працівника чи отримавшого каліцтво внаслідок нещасного випадку;

$D_{p д}$ - планова кількість робочих днів потерпілого від нещасного випадку зі смертельним наслідком чи каліцтвом у звітному періоді (році);

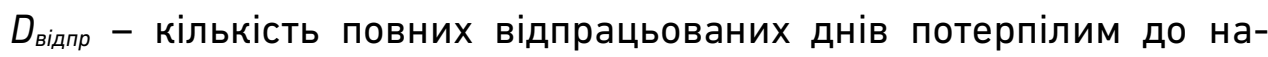
стання нещасного випадку зі смертельним наслідком чи каліцтвом у звітному періоді (році).

За даними Державної служби статистики України [7], кількість зайнятого населення у віці 60-70 років в процентному відношенні до населення зазначеної вікової групи сягало від 24,0\% у 2012 році до $13,6 \%$ у 2018 році відповідно. Тому не можливо оминути цю групу зайнятого населення при аналізі смертельного травматизму. Для потерпілих від смертельного травматизму працівників пенсійного віку враховується умовна працездатність лише до кінця поточного року. Розрахунок днів умовної непрацездатності від смертельних нещасних випадків потерпілих пенсійного віку здійснюється за формулою:

$$
D_{c \mu / \kappa}^{n}=\sum\left(D_{p d}-D_{\text {вiдnp }}\right) \text {, }
$$

де $D_{p д}$ - планова кількість робочих днів потерпілого від нещасного випадку зі смертельним наслідком чи каліцтвом у звітному періоді (році);

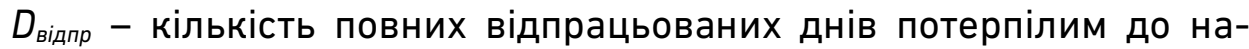
стання нещасного випадку зі смертельним наслідком чи каліцтвом у звітному періоді (році).

Підставивши (5) і (6) у (4) отримаємо вираз показника соціальних втрат від виробничого травматизму зі смертельним наслідком чи каліцтвом:

$$
K_{c . \text { B. }}^{c \mathcal{M} / \kappa}=\frac{\sum\left(\left[T_{n \beta}-T_{n}\right] \times D_{p \partial}-D_{\text {Bidnp }}\right)+\sum\left(D_{p \partial}-D_{\text {sidnp }}\right)}{N} .
$$

Отриманий вираз показника соціальних втрат від нещасних випадків зі смертельним наслідком чи каліцтвом дає можливість більш точно й об'єктивно проводити аналіз такого травматизму з урахуванням трагічності наслідків ніж за виразом (3). Однак і цей показник 
має недолік, що виражається у припущенні безперервності умовної професійної зайнятості постраждалих працівників від смертельних нещасних випадків чи випадків з каліцтвом до досягнення ними пенсійного віку, що в наших реаліях припустити складно.

3 метою апробації запропонованої методики аналізу смертельного виробничого травматизму з урахуванням найтрагічніших нас-

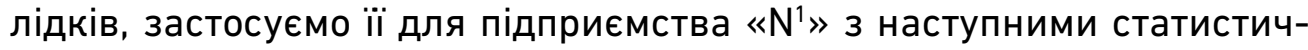
ними даними (таблиця).

Таблиця

Дані показників нещасних випадків зі смертельним наслідком на підприємстві «N» впродовж 2012-2016 рр.

\begin{tabular}{|c|c|c|c|c|c|c|}
\hline Рік & $N$ & $\begin{array}{c}\text { Кількість } \\
\text { смертельних } \\
\text { НВ }\end{array}$ & $\begin{array}{c}T_{\pi}, \\
\text { роки }\end{array}$ & $\begin{array}{c}D_{\text {відпр, }} \\
\text { дні }\end{array}$ & $\begin{array}{c}D_{C M} \\
\left(D^{n}{ }_{C M}\right), \\
\text { дні }\end{array}$ & $K^{C M}{ }_{C . B}$ \\
\hline 2012 & 245 & 1 & 32 & 15 & 7485 & 30,6 \\
\hline 2013 & 238 & $5^{*}$ & $\begin{array}{l}23 \\
67 \\
63 \\
51 \\
29\end{array}$ & $\begin{array}{l}123 \\
123 \\
123 \\
123 \\
123\end{array}$ & $\begin{array}{c}9627 \\
127 \\
127 \\
2627 \\
8127\end{array}$ & 86,7 \\
\hline 2014 & 243 & 2 & $\begin{array}{l}40 \\
36\end{array}$ & $\begin{array}{c}212 \\
45\end{array}$ & $\begin{array}{l}5288 \\
6555\end{array}$ & 48,3 \\
\hline 2015 & 251 & $4^{*}$ & $\begin{array}{l}55 \\
51 \\
64 \\
25\end{array}$ & $\begin{array}{l}65 \\
65 \\
65 \\
65\end{array}$ & $\begin{array}{c}1688 \\
2685 \\
188 \\
9185\end{array}$ & 54,8 \\
\hline 2016 & 235 & 1 & 38 & 164 & 5836 & 24,8 \\
\hline
\end{tabular}

Примітка: * - груповий нещасний випадок.

Аналіз отриманих даних за запропонованою методикою показав, що за найбільшою кількістю смертельних нещасних випадків на підприємстві (5 у 2013 році), показник втрат від смертельного травматизму є найбільшим - 86,7. За мінімальної кількості нещасних випадків зі смертельним наслідком показник втрат набував найменших значень, аж до мінімального за одного смертельного нещасного випадку.

Динаміка зміни показника соціальних втрат від нещасних випадків зі смертельним наслідком та їхній розподіл за роками спосте-

1 Дані по смертельному травматизму на підприємстві взяті з актів форми Н-1. Для розрахунків прийнято пенсійний вік 62 роки. 
реження на досліджуваному підприємстві наведений на рисунку.

3 рисунку видно, що значення показника соціальних втрат визначеного за формулою (7) та його динаміка впродовж звітного періоду повторює розподіл смертельних нещасних випадків за той же період за умови незначної зміни загальної чисельності працівників підприємства.

Значення показника соціальних втрат від нещасних випадків зі смертельним наслідком чи каліцтвом отримуються в результаті ділення на показник загальної чисельності працівників на підприємстві, яка з року в рік не є постійною. Коливання загальної чисельності працівників підприємства впродовж звітного періоду знижують точність показника соціальних втрат від смертельного виробничого травматизму.

При аналізі отриманих даних показника соціальних втрат та співставлення їх з динамікою смертельного виробничого травматизму встановлено, що найбільш точно цей показник дає якісну оцінку останньому при зміні загальної чисельності працівників підприємства до 7\%, що в умовах сьогодення малоймовірно. Тому для аналізу і оцінки соціальних наслідків від смертельного виробничого травматизму за наведеним показником можна використовувати середню чисельність працівників на підприємстві за період спостереження $\left(N_{c p}\right)$.

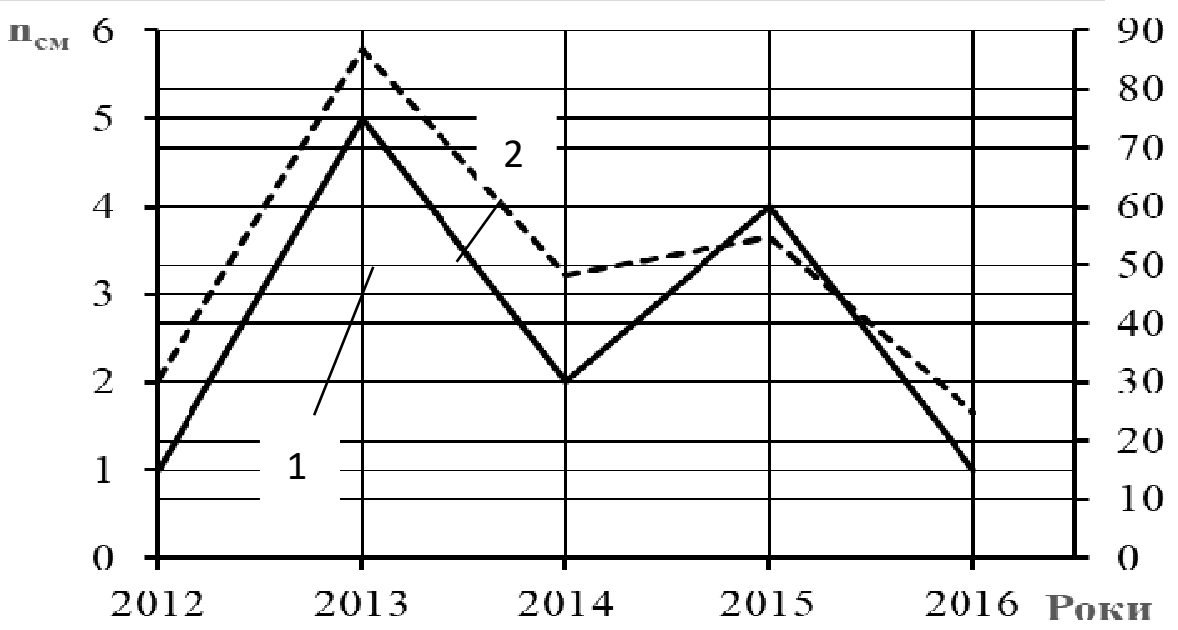

Рисунок. Розрахункова динаміка показника соціальних втрат від смертельного виробничого травматизма на фоні його розподілу по роках звітного періоду:

1 - рівень нещасних випадків на виробництві зі смертельним наслідком; 2 - зміна показника соціальних втрат 
Отже, при проведенні аналізу виробничого травматизму статистичним методом за наявності смертельних нещасних випадків та випадків з каліцтвом пропонується використовувати показник соціальних втрат. Цей показник дозволяє не тільки розширити можливості даного методу аналізу виробничого травматизму, а й більш точно й об'єктивніше оцінювати наслідки для суспільства такого небажаного явища, як смертельний виробничий травматизм.

1. Ткачук К. Н., Кружилко О. Є. Прогнозування виробничого травматизму : монографія. К. : Основа, 2014. 345 с. 2. Таірова Т. М. Методологічні засади моніторингу виробничого травматизму : монографія. К. : «Основа». 2014. 201 c. 3. Decent work indicators: guidelines for producers and users of statistical and legal framework indicators: ILO manual: second version / International Labour Office. Geneva: ILO, 2013. 257 р. 4. Гогіташвілі Г. Г., Карчевській Є. Т., Лапін В. М. Управління охороною праці та ризиком за міжнародними стандартами : навч. посіб. К. : Знання, 2007. 367 с. 5. Лесенко Г. Г., Масюкевич О. М., Мішукова Н. Б. Оцінка ступенів ризику нещасних випадків. Проблеми охорони праці в Україні. 2007. Вип. 14. С. 23-27. 6. Третьяков О. В., Харченко І. П., Піхота Я. С. Підвищення достовірності показників статистичного методу оцінки виробничого травматизму. Комунальне господарство міст. 2015. Вип. 120 (1). С. 69-74. 7. Рівень зайнятості населення за статтю, віковими групами та місцем. URL: http://www.ukrstat.gov.ua (дата звернення 26.05.2019).

\section{REFERENCES:}

1. Tkachuk K. N., Kruzhylko 0. Ye. Prohnozuvannia vyrobnychoho travmatyzmu : monohrafiia. K. : Osnova, 2014. 345 c. 2. Tairova T. M. Metodolohichni zasady monitorynhu vyrobnychoho travmatyzmu : monohrafiia. K. : «Osnova». 2014. 201 s. 3. Decent work indicators: guidelines for producers and users of statistical and legal framework indicators: ILO manual: second version / International Labour Office. Geneva: ILO, 2013. 257 r. 4. Hohitashvili H. H., Karchevskii Ye. T., Lapin V. M. Upravlinnia okhoronoiu pratsi ta ryzykom za mizhnarodnymy standartamy : navch. posib. K. : Znannia, 2007. $367 \mathrm{~s}$. 5. Lesenko H. H., Masiukevych O. M., Mishukova N. B. Otsinka stupeniv ryzyku neshchasnykh vypadkiv. Problemy okhorony pratsi v Ukraini. 2007. Vyp. 14. S. 23-27. 6. Tretiakov O. V., Kharchenko I. P., Pikhota Ya. S. Pidvyshchennia dostovirnosti pokaznykiv statystychnoho metodu otsinky vyrobnychoho travmatyzmu. Komunalne hospodarstvo mist. 2015. Vyp. 120 (1). S. 69-74. 7. Riven zainiatosti naselennia za stattiu, vikovymy hrupamy ta mistsem. URL: http://www.ukrstat.gov.ua (data zvernennia 26.05.2019). 
Shatalov 0. S., Candidate of Agricultural Sciences (Ph.D.), Associate Professor, Kuskovets S. L., Candidate of Engineering (Ph.D.), Associate Professor (National University of Water and Environmental Engineering, Rivne)

\section{METHODOLOGICAL BASES OF EVALUATION OF FATAL OCCUPATIONAL INJURIES SOCIAL CONSEQUENCES}

The necessity of monitoring of occupational injuries for the development of programs of measures for its prevention and reduction is indicated. Classical indicators that reflect the dynamics of occupational injuries are presented. Its disadvantages are evaluated, especially in the assessment of accidents with a fatal outcome or injury to an employee.

It is determined that the main disadvantage of occupational injuries in assessing accidents with a fatal result is only a quantitative estimation. The absence of consideration of the social component of fatal injuries is an imperfection of the methods of analysis of occupational injuries. The analysis of attempts presented in the scientific and normative literature to assess the consequences of fatal injuries by various indicators shows that they have a number of limitations in the application, and do not always accurately and objectively reflect its dynamics. The purpose of this research is to develop ways to increase the reliability and objectivity of the statistical method of analysis of occupational injuries with a fatal results or injury using the indicator of social consequences. The presented indicator takes into account the number of days of conditional disability of workers with which there were accidents with a fatal result. Such conditional incapacity is proposed to take into account the days of possible occupational activity of employees until reachable by their retirement age, provided that there are no accidents with a fatal result. The approbation of the proposed indicator of social losses from fatal occupational injuries is presented. It is based on the data of the current enterprise. The dynamics of the indicator of social losses from fatal occupational injuries and its values by the years of the reporting period are presented. The conditions for using the proposed indicator are given. The basic condition for the accuracy and objectivity of this indicator is the small turnover of personnel at the enterprise. It was established that if the number of employees changes by no more than $7 \%$ during the 
reporting period, the proposed indicator of social losses most accurately and objectively assesses the effects of fatal occupational injuries.

Keywords: analysis, method, effects, indicator, labor, injury, factor.

Шаталов А. С., к.С.-Х.н., доцент, Кусковец С. Л., к.т.н., доцент

(Национальный университет водного хозяйства и

природопользования, г. Ровно)

\section{МЕТОДОЛОГИЧЕСКИЕ ОСНОВЫ ОЦЕНКИ СОЦИАЛЬНЫХ ПОСЛЕДСТВИЙ СМЕРТЕЛЬНОГО ПРОИЗВОДСТВЕННОГО TРАВМАТИЗМА}

Приведён анализ количественных показателей статистического метода определения производственного травматизма при оценке его последствий. Указаны недостатки классических методик оценки смертельного производственного травматизма. Предложена методика определения показателя потерь с возможностью учета социальных последствий от несчастных случаев со смертельным исходом и в случае увечья. Установлены пределы и условия использования предложенного показателя тяжести последствий смертельного травматизма. Осуществлена апробация предложенного показателя при анализе производственного травматизма.

Ключевые слова: анализ, метод, последствия, показатель, труд, травматизм, фактор. 